Western University Scholarship@Western

Centre for the Study of International Economic Centre for the Study of International Economic

Relations Working Papers

Relations

1983

\title{
Rent Seeking in India: Its Costs and Policy Significance
}

Sharif Mohammad

John Whalley

Follow this and additional works at: https://ir.lib.uwo.ca/economicscsier_wp

Part of the Economics Commons

Citation of this paper:

Mohammad, Sharif, John Whalley. "Rent Seeking in India: Its Costs and Policy Significance." Centre for the Study of International Economic Relations Working Papers, 8304C. London, ON: Department of Economics, University of Western Ontario (1983). 
CENTRE FOR THE STUDY OF INTERNATIONAL ECONOMIC RELATIONS

WORKING PAPER NO. $8304 \mathrm{C}$

RENT SEEKING IN INDIA:

ITS COSTS AND POLICY SIGNIFICANCE

\author{
Sharif Mohammad \\ and \\ John Wha1ley
}

Department of Economics Librany

APR 111983

University of Western Ontario

This paper contains preliminary findings from research work still in progress and should not be quoted without prior approval of the author.

\author{
DEPARTMENT OF ECONOMICS \\ UNIVERSITY OF WESTERN ONTARIO \\ LONDON, CANADA
}




\section{RENT SEEKING IN INDIA: \\ ITS COSTS AND POLICY SIGNIFICANCE ${ }^{1}$}

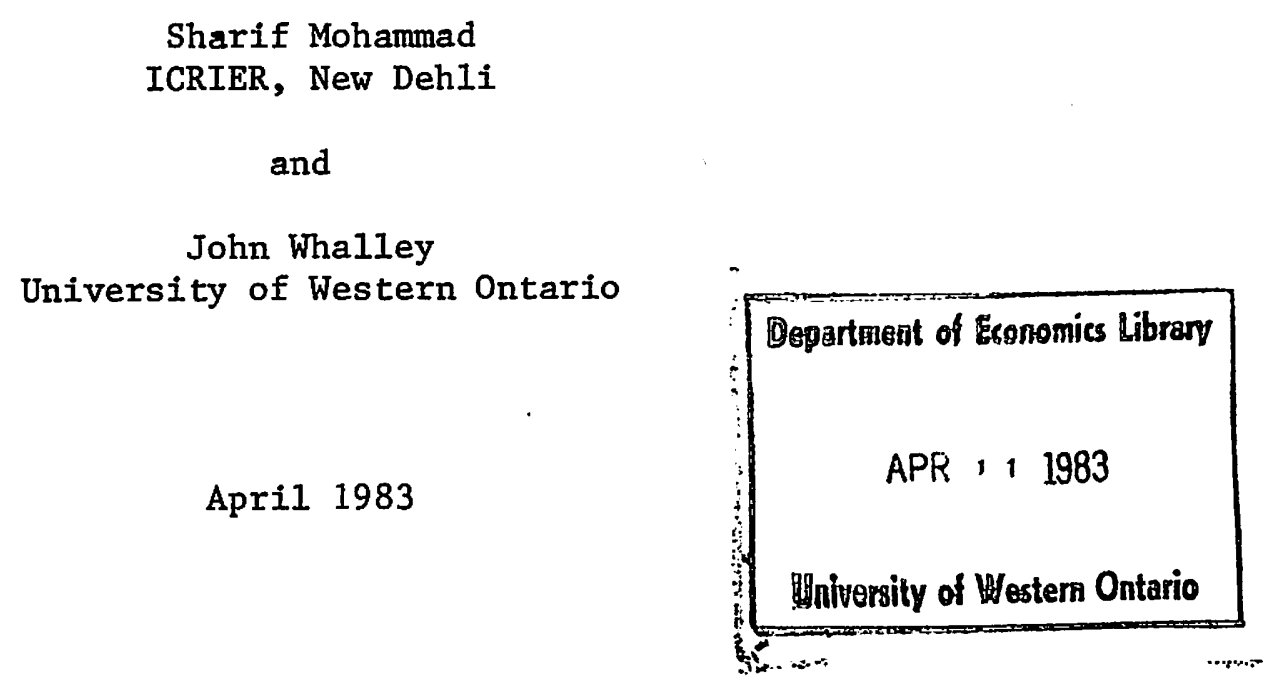

$1_{\text {We are grateful to a seminar group at Western Ontario for comments. }}$ 
I. Introduction

In a pioneering paper in 1974, Anne Krueger both formalized the notion of rent seeking and suggested its importance in the analysis of distortions. In her paper, Rrueger argued that the annual welfare costs of rent seeking induced by a system of price and quantity controls can be approximated by the value of rents created, and presented some initial calculations for both India and Turkey. She suggested that annual losses are around $7 \%$ of GNP in the Indian case, with somewhat larger losses for Turkey. Subsequent literature following Krueger's paper has focussed almost exclusively on the analytics of rent seeking, stressing its potential significance in international trade theory and other areas. 1

In this paper we return to the numerical issue of the size of the cost of rent seeking and re-examine Krueger's earlier calculations for India. We follow Krueger's procedure of approximating rent-seeking costs by the value of rents created by controls, even though it is now agreed that this result is only an approximation. While there is a substantial amount of ambiguity both as to which controls in India generate rent seeking and exactly how the rent seeking works, we nonetheless suggest that the annual costs of rent seeking in India seem likely to significantly exceed Kruegers' figure of $7 \%$ of GNP.

In making our calculations, we have tried to err on the conservative side, but in spite of this the range we produce in our estimates is between $30 \%$ and $45 \%$ of GNP per year. We suggest that these numbers put rent seeking in India into an entirely different category from more traditional policy issues such as trade liberalization, tax reform, and the like, both because of its policy significance and its potential role of impeding the development process.

${ }^{1}$ See, for example, Bhagwati and Srinivasan (1980), Bhagwati (1982), and the collection of papers on rent seeking in Buchanan, Tollison, and Tullock (1980). 
The main sources of rent seeking are the system of price controls and rationing in goods and financial markets which appear more important in tèrms of rent seeking costs than the quantity controls in foreign trade stressed by Krueger.

From a Western standpoint the Indian economy presents quite an extraordinary complex of interlinking controls covering most areas of the economy. Many commentators on India have remarked on the paradox of extremely low capacity utilization rates in some industries, but a high marginal productivity of capital in full capacity industries. A further observation frequently made is that of substantial overmanning in manufacturing and other urban activity. ${ }^{1}$ We suggest that much of this excess factor use has its origins in rent-seeking behaviour. Estimates of capacity utilization rates of $60 \%$ or less, and overmanning levels of $50 \%$ or more of the manufacturing work force are thus roughly consistent

with the ranges we suggest for aggregate loss estimates from rent seeking. Different problems apply to agriculture but similar orders of inagnitude can easily occur. $^{2}$ When combined with a large public sector employment, much of which is implicitly devoted to coordinating the rent-seeking process, the large numbers we report seem to us to be plausible. While other factors beyond rent seeking can explain some of this large idle factor employment, it seems to us that rentseeking behaviour is likely to be a major source.

The estimates presented here are also approximately consistent with some of the recent estimates of the size of the black economy in India. ${ }^{3}$ If the size of the black economy reflects rent generated by controls, its size is also

\section{${ }^{1}$ Desai (1981).}

2 Some of the estimates of underutilization of land, particularly by large farmers (Sau 1976), and those of surplus labour in Indian agriculture (e.g., Rudra (1973), Mitra (1976)) seem to support the figures we suggest. While not all of the underutilization is due to rent seeking, the incentives for rent seeking are clearly present and seem to us to be important.

3 Gupta and Gupta (1982), Gupta and Mehta (1982). 
related to rent seeking costs.

Our calculations also have a wider relevance to recent literature on the costs of distortions, much of which is based on the earlier work of Hotelling (1938) and Harberger (1964). We suggest that, other things being equal, welfare losses induced by rent seeking are likely to be larger than those originating from traditional price distortions. With price distortions (such as an ad valorem tax), resources are misallocated to less desirable uses but, importantly, remain in use. With rent seeking, resources are either made idle or used in processes generating outputs with no welfare valuation. This observation suggests to us that further numerical work on the costs of rent seeking activity and the analysis of other less traditional distortions which generate unutilized resources as a feature of a competitive equilibrium ${ }^{1}$ may be a fruitful direction for future work on the costs of distortions to follow.

\section{A Simplified Treatment of Rent Seeking}

To illustrate how rent seeking works and its applicability to India, we begin by considering the same situation discussed by Krueger; the impact of a quota on imports. A compact way of presenting the main features of rent seeking is through a simple partial equilibrium demand-supply diagram for imports In Figure 1 we consider a small open economy facing a perfectly elastic world supply function for a single import at the world price $\mathrm{P}_{W}$. With no restrictions on foreign trade the quantity of imports is $q_{e}$; with an import quota imposed at $\bar{q}$ domestic prices increase to $P_{D}$.

The price differential $\left(P_{D}-P_{W}\right)$ created by the quota $\bar{q}$ would also result from: an import tariff set at a rate $t^{\prime}=\left(P_{D}-P_{W}\right) / P_{W}$. The traditional approach

${ }^{1}$ An example is Harris-Todaro equilibria which are a special case of the more general formulation of equilibrium in the presence of rent seeking. 
to the analysis of quotas has thus been to stress the equivalence of tariffs and quotas, and (in partial equilibrium analysis) to calculate the consumer surplus welfare loss. This is represented in Figure 1 by the triangle under the (compensated) demand function $\mathrm{D}_{\mathrm{M}}$.

Rent seeking, however, suggests that quotas and tariffs are not equivalent (especially in LDC's) since tariffs generate revenue for the government while quotas do not. In most LDC's quotas are issued by government agencies rather than auctioned or sold. Applications for quotas are vetted by government officials who evaluate them on the basis of the applicant's 'need' for imports. Thus, machinery, raw materials, and energy imports all have to be justified to bureaucrats who must then allocate the quota between the competing requests.

This justification procedure is how rent seeking activity arises. If quota is obtained, users of imports pay the world price $\mathrm{P}_{\mathrm{W}}$ but can effectively sell imports (usually after further fabrication) at the higher price $P_{D}$. Potential importers will thus be willing to use resources up to $\left(P_{D}-P_{W}\right)$ per unit import in seeking out a quota, if use of those resources guarantees an allocation of quota. The types of activities involved are to install excess capacity to justify quota requests for raw material imports on the grounds these are needed for use along with the installed capacity, hiring additional labour to justify quota for capital machinery imports to use the labour, resource use in presenting and promoting the case for each application with the bureaucrats involved, and other socially wasteful activity.

In the simple formulation used in Figure 1 it is easiest to think of quota as being awarded to the applicant who spends the most resources per unit in quota seeking activities. In this case, competition among rent seekers results in each successful applicant spending $\left(P_{D}-P_{W}\right)$ per unit import quota, 


\section{Figure 1}

Partial Equilibrium Analysis of Rent Seeking

Induced by a Quota on Imports




generating a volume of applications equal to $\bar{q}$. This produces an additional welfare loss, beyond the consumer surplus triangle, from these activities of $\left(P_{D}-P_{W}\right) \cdot \bar{q}$ equal to the amount of rent created by the quota restriction. This is displayed in Figure 1 as the rectangle of losses induced by rent seeking.

In practice, the rent seeking process is more complex than that discussed above. Some rents are allocated in ways which are largely unaffected by rent seeking activity. In the extreme case where rent seeking does not change the probability that an agent will receive an allocation of a rent, clearly no rent seeking activity results. In intermeditate cases where this probability is changed by rent seeking but not modified from 0 to 1 by outspending other rent seekers, the costs involved will equal only part of the rent created by the control. The treatment in the diagram above thus assumes a competitive rent seeking process with rent allocation made by bureaucrats only on the basis of resources expended per dollar of rent awarded.

A further qualification to the treatment above is that the overinstallation of capacity or excess labour hiring associated with rent seeking will typically not have a zero marginal product. If labour and capital are perfectly substitutable in production both factor inputs would be fully utilized in the rent seeking firm. Rent seeking costs are thus to be thought of as the welfare cost of excess investment and labour use in rent seeking firms. In a complete general equilibrium model changes in the marginal product of capital and labour as factor hiring is changed due to rent seeking would be captured. Only under special conditions will the welfare cost of rent seeking equal the value of rents created by controls as assumed by Krueger, even though we make that assumption here for ease of calculation. 
III. Policy Interventions and Controls in the Indian Economy

Before presenting our estimates of the costs of rent seeking in India we provide an overview of the main areas of controls and policy interventions in India for readers unfamiliar with Indian institutions. These controls have been grouped under the headings of external sector controls, capital market controls, goods markets controls (including agricultural policies, and price controls) and labour markets controls.

\section{1) External Sector Controls}

Import 1icensing and Foreign Exchange Rationing: By far the most important of the external sector controls is the system of import licensing. The most striking characteristic of the present licensing system is its complexity. Importers are classified into various categories, which along with the type of import involved, determines the policies and procedures which apply in allocating licenses. Distinctions are made between 'registered exporters', public sector and private sector importers, Actual Users of imports (AUs), Established Importers (EIs), DGTD ${ }^{1}$ units, SSI $^{2}$ units, Non-DGTD-Non-SSI units, other institutions (non-industrial), all of which are governed by a different set of procedures and policies. These categories of importers produce 16 main types of licenses, each with several sub-categories. In the 'registered exporters' category, for instance, a distinction is made between manufacturer-exporters, merchant-exporters, and export houses. Each type of license is governed by its own procedures and carries its own list of items, each subject to different forms of restriction. Different regulations apply, for instance, to licenses for capital good imports and imports of raw materials, spares and components.

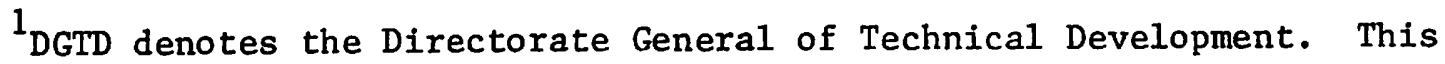
agency evaluates technical characteristics of firms for investment licenses. Qualifying firms then receive separate treatment for import licenses.

${ }^{2}$ SSI denotes Small Scale Industrial Units. Industries are classified on the basis of scale in Industrial Policy Resolutions and this classification also affects import licenses. 
Commodities for which licenses are issued also involve differentiation in licensing procedures. There are restricted items, banned items, items subject to specified export-import links, items subjected to quotas linked to a specific industry, and items on an Open General Licensing list (OGL).

The form and degree of these quite extraordinary restrictions also changes over time. In recent years, licenses given to established importers (mostly traders) have been declining and those given to Actual Users (AUs) have been increasing.

The allocation of import licenses to the various industries is supposed to be guided by the production targets fixed by the Planning Commission and allocations to firms in each industry guided by criteria of 'essentiality' and 'non-availability'. The value of import licenses issued to firms in both the private and public sectors is usually based on production capacity (or the level of production in the previous two to three years). As a result industrial licensing policies (or investment licensing) are closely related to import licensing, and for imported plant and machinery a Capital Goods Committee must give its import license approval first, before the installation proposal can subsequently go before an Industrial Licensing Comnittee for approval.

Import licensing coexists with a protective tariff system. Tariff rates in India range up to a maximum of 450 percent, with around $40 \%$ of imports facing tariffs between 75 and 120 percent. Items involving higher degrees of processing generally receive greater nominal tariff protection than items with low degrees of processing. Capital goods are generally subject to lower levels of tariffs than consumer goods or raw materials. However, because of the dominant role of import licensing and stringent controls on foreign exchange, tariffs are largely unimportant as a mechanism for affecting import flows

\footnotetext{
${ }^{1}$ Such as missions abroad, embassies, debt repayment, etc.
} 
since these are largely quantity constrained. Tariffs do affect the value of rents created by the import licensing system and affect our calculations of welfare costs of rent seeking presented below.

Export Controls and Export Promotion: Indian export policies also generate rent seeking since these involve controls and bans on export of certain items along with export incentives for other products. Incentive schemes link import licenses with export performance (the so-called 'replenishment' scheme) and provide duty drawbacks, cash assistance, and other indirect incentives to export units.

The list of items subject to export control covers items considered 'essential' for domestic consumption, most of which are in short supply due to price and other controls. Items completely banned include oil seeds, sugar cane, paraffin wax and poultry; but this list and the degree of restriction involved continually changes.

Important direct export promotion incentives are cash assistance, priority import 1icenses for exporters, and duty drawbacks. Among indirect incentives are exemptions from various taxes, freight concessions, and cheap export-credit facilities. The scope and coverage of export incentive schemes continues to expand, and in recent policy pronouncements for (981-82 and 1982-83) more incentives have been awarded both to export houses and 100 percent export-oriented-units (both within the export processing/trading zones and outside). A 5-year tax holiday to such units now applies on top of the other incentives given to manufacturer-exporters in the country.

The entire scheme of export incentives like other controls in India is extremely complex. According to one study "an exporter, to finally complete his export transaction, has to deal with 9 tolo organizations and also to prepare a large number of copies of different types of applications". Typically the

\footnotetext{
${ }^{1}$ Report of the Committee on Import-Export Policies and Procedures.
} 
time involved in completing this process is large.

A final but important feature affecting Indian trade policy is state trading or "canalization". There are, at present, about 25 state trading agencies in India for imports and exports which handle about 200 products. The broad groups are cotton, silk, films, metals, chemicals, pharmaceuticals, steel, electronics,. petroleum products, fertilizer, cement, oil seeds, and newsprint. The more important agencies are the State Trading Corporation, the Minerals and Metals Trading Corporation, the State Chemicals and Pharmaceuticals Corporation, and the Handloom and Handicrafts Corporations. Much of the rent seeking activity in the foreign trade area in India thus involves state agencies seeking rents allocated by other government agencies.

2) Capital Market Controls

Industrial licensing: The most important set of capital market controls are to be found in the industrial licensing system under which approval must be obtained prior to making any investment in plant and machinery, structures, or other capital equipment. The objective of these controls is to regulate investment flows while providing preferences to small business who are exempt from the licensing procedures.

Licenses are issued to both private and public sectors according to targets and priorities set by the Planning Commission. ${ }^{1}$ Since 1956 a list of industries designated as exclusively for the public sector has limited private sector investment; these include atomic power, iron and steel, heavy plant and machinery, air transport, railways, coal, shipbuilding, and communications.


Trade Practices (MRTP) Companies) and Foreign Exchange Regulation Act (FERA) companies (those with more than $40 \%$ foreign equity) who can only invest in a few selected industries. 
Other industries are grouped under various schedules which allow public, private, small scale and foint operations; a few industries do not require a license. Important industries where joint public and private ventures are encouraged are chemicals, fertilizer, road and sea transport, synthetic rubber, drugs and pharmaceuticals, and some metal industries.

The procedures followed in granting industrial licenses are extremely complicated and take a considerable amount of time. The application for an industrial license has to go through an approval process involving several different agencies before reaching the final granting authority-- the Industrial Licensing Committee of the Government. Two of the more important steps involve the Capital Goods (CG) Licensing Committee, which approves the import of capital goods and equipment, and the Directorate General of Technical Development (DGTD), which evaluates and approves each application on 'techno-economic' considerations, such as the method of production, costs, and capacity. The application also has to be approved by the ministry involved before it finally goes before the Industrial Licensing Committee. There are also special procedures for export industries (or units), investments involving expansion in MRTP and FERA companies, and the issuing of licenses to new investors.

License allocation procedures have also been modified over the years. For example, the license free limit for capital investment in plant and equipment for small scale units has been recently raised to Rs. 2 million (around $\$ 250,000$ ). These units are also entitled to preferential treatment for cheap loans, import licenses, and protection from competititon with larger industrial firms. At present, about 400,000 small scale units are in operation, producing more than 800 items from the production of which large 
firms are excluded. ${ }^{1}$

Controls on Foreign Private Investment: A further set of investment controls effectively excludes foreign investment in India. Industrial policies control the list of industries where foreign collaboration is permitted, or where no participation of foreign firms is allowed. A separate committee approves applications for collaboration between domestic and foreign firms. Foreign participation in consumer goods industries is completely banned. In other areas, restrictions on collaborative activity operate as disincentives to foreign firms, such as restrictions on exports to certain countries, and requirements on employment of domestic workers.

Subsidies, Cheap Loans, and Priority Allocation of Loans: In addition to the licensing system, controls over financial institutions are used to target funds to chosen priority sectors, interfering with the limited capital market which exists. The Industrial Development Bank of India (IDBI), the Industrial Finance Corporation, the Industrial Credit and Investment Corporation all provide cheap loans to priority sectors at concessional rates. For example, comercial banks currently change $11 \%$ on short-term loans to exporters. The Reserve Bank of India (RBI) also gives a $1.50 \%$ subsidy to the banks on such 1 loans. The IDBI also gives loans to exporting firms (mainly medium term loans) at concessional rates of 6 to $6.50 \%$ per annum. ${ }^{2}$

For small scale units, the government has set up a Credit Guarantee Corporation which insures loans provided by commercial banks. Up to $75 \%$ of such credit is fully insured (or guaranteed) by this agency. A similar agency has been set up for export credit provided by the banks (the Export Credit Guarantee Corporation).

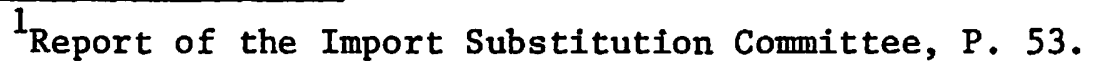

2 The inflation rate is currently around 15 percent in India.
} 
The allocation of credit to agriculture is regulated by the RBI through the Agricultural Refinance Corporation. The government also has regional rural banks to provide credit to small farmers, landless workers and others who do not receive credit from commercial banks. All loans to agriculture are generally given at concessional rates.

Interest Rates Controls: An especially important set of capital market controls involve the regulation of deposit and lending rates of commercial banks, cooperative banks and other public sector financial institutions. The government fixes a ceiling on rates charged by banks on credit to export units, small scale sector units, and agriculture. Recent regulations control lending rates of commercial banks to between $13.50 \%$ to $19.50 \%$, while the ceiling on deposit rates of these banks is $10.00 \%$. Ceilings on government company deposit rates are $9 \%$ to $16 \%$ depending upon the period of deposit, and the public companies'rates are $11 \%$ to $13.50 \%$.

Lending rate ceilings on loans for export and food procurement activity are controlled at $12.50 \%$, while the ceiling rate of term-lending institutions (mainly to industry) is set at 14\%; credit to small scale industry is controlled between 12 and $14.50 \%$ (issued mainly from state finance corporations). There are also controls on rates on interbank loans which are currently between $8.50 \%$ and $10 \% .^{1}$

Monopoly Controls: A final set of capital market controls are aimed at the monopoly power of large industrial and business houses (MRTP Companies). These restrictions limit the activities of large firms through controls on investment or the setting up of new plants. Denying new licenses to large firms and awarding them instead to other inexperienced private entrepreneurs or state corporations has resulted in small amounts of new capacity being installed 
in several important sectors such as paper, cement and fertilizer. More recently the government has started giving licenses to certain large firms in violation of the MRTP Controls and revising the list of industries covered, but the distortions of capital markets associated with these controls remain.

\section{3) Controls in Goods Markets}

Price Controls: Price controls in India are extensive. The Government controls prices of several important categories of commodities, such as food grains, sugar, kerosene, cement, and fertilizer, while also regulating their supply through public distribution. Other goods such as cars, scooters, trucks, drugs, steel, paper products, and certain textiles, are also price controlled but distributed through non-government agencies.

In the case of food grains, the government subsidizes a portion of consumption $^{1}$ by selling at a lower price than that ruling in the open market. In addition, there are procurement (and support) prices for food grains on top of which government levies are added at the time of harvest in surplus areas. By periodically banning interstate movement of food grains and more widely controlling prices, the government also tries to control private traders' profits from sales in deficit areas. 2

With sugar, the government procures a large portion of total production through compulsory deliveries from sugar producers, which it sells at low prices to ration card holders in the cities but with a limit on the quantity per person. The government also sells significant amounts to traders and other users at a higher price (the free sale price). The market price of sugar thus reflects the

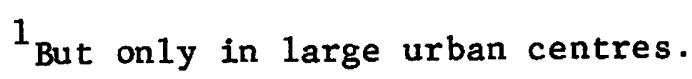

For a detailed discussion of Indian agricultural price policies, see Rajkrishna (1967), Mellor (1968) and Gupta (1980). 
amount released by the government for free sale each month. 1

Most other commodities under price control such as cement, steel, and automobiles are under general price controls. A common practice is to secure allocations on whatever pretext can be justified and resell in the open market at a large premium (ranging from $100 \%$ to $200 \%$ or even more). Such black market activity is, of course, illegal but widely practised. While there is no firm data to appeal to, it is widely agreed that larre portions of the total cement and steel production, for instance, are traded in black markets.

Pricing Policy of Public Enterprises: Public enterprise pricing policies also form part of the system of price controls and are typically associated with significant shortages because of low controlled prices. These undertakings cover both public industrial and commercial undertakings, and public utilities. ${ }^{2}$ In the case of electricity and irrigation, prices of services are fixed so low that they do not cover marginal costs of production. In the transport sector, only railways among public enterprises have been able to earn positive accounting profits, while air transport has had large losses.

An especially important area where rent seeking is generated is the allocation of power provided by public utilities. Power shortages, breakdowns, and power cuts are commonplace in India, and given the low controlled price of power, rent seeking is a constant feature in the search for sustained power allocations to industrial plants.

Controls on Agriculture: The main agricultural items under price controls are food grains (wheat, rice, oilseed), sugarcane, and sugar. In fixing agriculture

\footnotetext{
Isee Chetty (1982) for a discussion of these pricing and distribution schemes.

Included are power plants, irrigation, railways, air transport, post, telegraph and communication (both the services provided and equipment used), road and sea transport, steel plants, fertilizer manufacturing, heavy electrical equipment manufacture, Hindustan Machine and Tools (a major enterprise in machinery), cement production, and coal mining.
} 
prices, government policies aim to assure 'fair' prices to farmers by fixing procurement prices and preventing wide price fluctuations. Most Indian economists agree that the result apprears to have been elevated agricultural prices from what free markets might produce. 1

In addition, various subsidy programmes operate involving land development, special aid to small and marginal farmers, subsidies to inputs (including water), fertilizer, and seeds. The government has also promoted new production techniques, the use of pesticides, HYV seeds, multiple cropping, use of tractors, tillers, and harvesters. Subsidies and cheap credit are the usual vehicles for all these activities.

A final set of controls in agriculture is the land-ceiling law enacted as a part of more general land reforms. The main objective is to put a ceiling on individual land holdings in order to redistribute land to landless farmers. With agriculture being an area of responsibility for state rather than national government, these ceiling limits vary from region to region and seem, in practice, to have been largely avoided through artificial transfers of land in the names of relatives.

\section{4) Labour Market Controls}

No formal system of controls operates in labour markets, and these markets are perhaps the freest in India. While there are minimum wage rates in urban areas, these are generally low and cover only a small proportion of workers.

The main areas where labour market intervention is significant involves government worker pay scales. Government employees generally receive significantly higher real wages than comparable employees in private employment. ${ }^{2}$ This is the

\footnotetext{
${ }^{1}$ See Dantawala (1970), Rao (1975), Mellor (1969), Rajkrishna (1967).

${ }^{2}$ See Desai (1981), Fonesca (1975), Gupta (1976), and Sinha (1971).
} 
source of a considerable amount of rent seeking behaviour with individuals seeking government jobs through accumulation of educational qualifications, in many cases requiring a significant time input.

\section{Evaluating the Costs of Rent Seeking}

From the description in the previous section readers will have been able to gain some sense of the quite extraordinary coverage and complexity of controls in India. Almost every economic activity involves some contact with control and regulation on a scale quite outside the usual experience of Western economists. One's intuition is that the amount of rent-seeking behaviour these controls generate has to be large merely because they are so pervasive. As controls grow in complexity, bureaucratic discretion in administering the controls grows correspondingly and the scope for rent seeking expands.

Evaluating the cost of rent seeking, however, is a treacherous matter since the resources used in rent seeking are a function of the explicit or implicit rules used in allocating the rents which the controls create. Some cases are reasonably straightforward. If import licenses are allocated on the basis of 'need' then users of imports will overinstall capacity to generate the required 'need': If government jobs pay higher real wages than private sector jobs and are allocated on a 'qualifications' basis, individuals will overindulge in educational investment. Other cases are less obvious. If government regulations are introduced into credit markets with loans allocated on a priority basis then if the priorities are clearly specified no amount of rent seeking will change them. Our impression, however, is that in practice sufficient bureaucratic discretion remains in defining allocation rules, that when mixed with a little corruption, rent seeking behaviour nearly always pays. The fundamental 
difficulty in evaluating rent seeking costs, however, is clearly unearthing these allocation rules and tracing the rent seeking process through its various ramifications.

A further important issue is that a significant: amount of rent seeking activity seems to arise in areas of activity where government agencies of one king or another seem to be attempting to secure rents created by the regulatory power of other government agencies. While the private sector is, of course, heavily involved with rent seeking, a significant part of the overall picture concerns the government reallocating rents through a competitive process among its own agencies. An explanation of this phenomenon is that a single amorphous government agency is not a realistic representation of public sector activity in India. Since public sector managers respond to their own incentive structure. When combined with the profit opportunities from illegal dealings in black market activity, the incentives for rent seeking even by government agencies become a little clearer.

In calculating the costs of rent seeking in India we thus make the strong assumption that some form of rent seeking is involved with all the controls listed above. As in Krueger (1974), a calculation of the annual value of rents is assumed to be equated to an estimate of the annual rent seeking costs from controls. Ideally, a more sophisticated general equilibrium calculation as to how the economy would behave in the absence of controls would be desirable. We justify our present approach on the two grounds that such a complete general equilibrium calculation for India is, at present, outside our resources, and, perhaps more importantly, because we believe that our basic point that costs of rent seeking in India are in all probability very large would not be substantially affected 
We begin with Krueger's data which we reproduce in Table 1. Her estimate of the value of rents for 1964 is in the region of $7 \%$ of GNP, and is dominated by rents associated with import licenses and price controls. The estimated rent created by import licenses depends crucially on the value of the premium created by these quantity controls; estimated rents from price controls are based on the lower bound estimates due to Monteiro (1966). In our re-evaluation of the cost of controls we employ a similar approach to that used by Krueger, but our coverage is broader and the estimated size of rents correspondingly larger. Because a rent seeking activity involves intermediate (interindustry) as well as final transactions large rent-seeking costs as a fraction of GNP result. We follow a sequence similar to that in the preceding section in separately considering foreign trade controls, capital market controls, controls in goods markets (including agriculture), and finally labour market controls. We avoid double counting the rent seeking costs from any given controls under more than one of these categories.

\section{1) Foreign Trade Controls}

Here we focus on import licenses as the main source of rent seeking. Rent seeking costs associated with export related activity involving allocations of cheap loans enter through our treatment of capital market controls.

Figure 2 illustrates our approach to rent seeking costs of import controls. We assume a domestic import demand function $D_{M}$, a perfectly elastic world supply function $S_{M}$, and a quota $\bar{q} \cdot P^{D}$ is the domestic scarcity price, $\mathrm{P}^{\mathrm{T}}$ is the world supply price gross of tariffs. The domestic tariff thus partly reduces the welfare costs of rent seeking which equal $\left(P^{D}-P^{T}\right) \cdot \bar{q}$. 
Table 1

Krueger's Estimates of the Value of

Rents in India, 1964

Source of Rent

Public investment

Imports

Controlled commodities

Credit rationing

Railways

Total
Amount of Rent

(Rs. million)

365

10,271

3,000

407

602

14,645

$1_{\text {Krueger (1974) p. } 294 .}$ 
In evaluating the rents associated with import licenses the two main elements are the size of the import premium which licenses create and the value of licenses issued. Krueger assumes a premium of approximately $100 \%$ over world import prices. We make a similar assumption justifying this number not only on the grounds given by Krueger but also appealing to further literature references. Bhagwati and Srinivasan (1975, p.159), for instance, estimate the import premium on most of the import items they consider during the period 1968-69 to 1970-71 as being in the range between $70-100 \%$.

The value of licenses issued for imports in India in 1980-81 was 53.4 billion rupees compared with a total import bill of 122 billion rupees. ${ }^{1}$ on this basis we assume that the value of rents created by import licenses in 1980-81 was approximately equal to the value of licenses themselves when valued at world import prices, i.e., 53.4 billion rupees. This breaks down into separate license figures of 27.8 billion rupees for imports by government agencies and 25.5 billion for imports by private agencies. Since most of the imports by government agencies were for distribution through government trading agencies, the rent-seeking activity which takes place in these cases arises as private firms and government enterprises seek access to government distributed imports.

In estimating the rents created by foreign trade controls we also subtract the tariffs collected on imports from the rents created by licenses since the tariff offsets part of the effect of the quantity controls. Total tariff collections in 1980-81 were 33.4 billion rupees on a gross basis, net of refunds these

${ }^{1}$ In recent years there has been some liberalization of import controls with increasing numbers of items added to the open general licensing system. In 1970-71 the value of licenses issued was approximately the same as the value of imports at 16.3 billion rupees. 


\section{Figure 2}

Rent Seeking Costs From Import Controls




were approximately 32 billion rupees. We subtract approximately half of this to reflect the ratio of licenses to total imports in 1980-81 giving an overall figure of approximately 37 billion rupees as the cost of rents originating from import controls. This is a considerably smaller fraction of GNP than in Krueger's calculations reflecting both the liberalization of import controls through the late $1970^{\prime}$ 's in India and the effects of tariffs.

There are no precise data for $1980-81$ on which to base the rent seeking costs associated with export incentives. Export cash subsidies in the late 1970's are around Rs. 4 billion. ${ }^{1}$ Assuming these generate a corresponding amount of rent seeking activity yields an annual cost of rent seeking associated with foreign trade controls in 1980-81 of around Rs. 40 billion.

\section{2) Captial Market Controls}

In the capital market area we calculate the annual cost of rent seeking per rupee of capital as the difference between the real rate earned by capital users, $r_{u}$, (the marginal product of capital) and the real rate of return paid to savers, $r_{s}$. WE multiply this difference by the annual value of household savings, $s$, to obtain an estimate of the annual rent seeking loss from capital market controls. This is illustrated in Figure 3. This procedure focuses on the flow loss from rent seeking associated with the allocation decisions affecting newly generated capital (including replacement investment) each year.

The wedge between the return to savers and the marginal product of cpaital reflects the twin features of regulation of deposit and lending rates of financial institutions and the priority system of allocation of loans. The effect of the priority system is to produce differences in the marginal product of capital by industry since the capital market is not allowed to work effectively and equalize the rates of return to capital in all uses. We use an averaged

${ }^{1}$ See Bhagwati and Srinavasan (1975), Datta (1978), Verghese (1978), and Raghavachari (1979). 


\section{Figure 3}

\section{Rent Seeking Associated with Capital Market Controls}

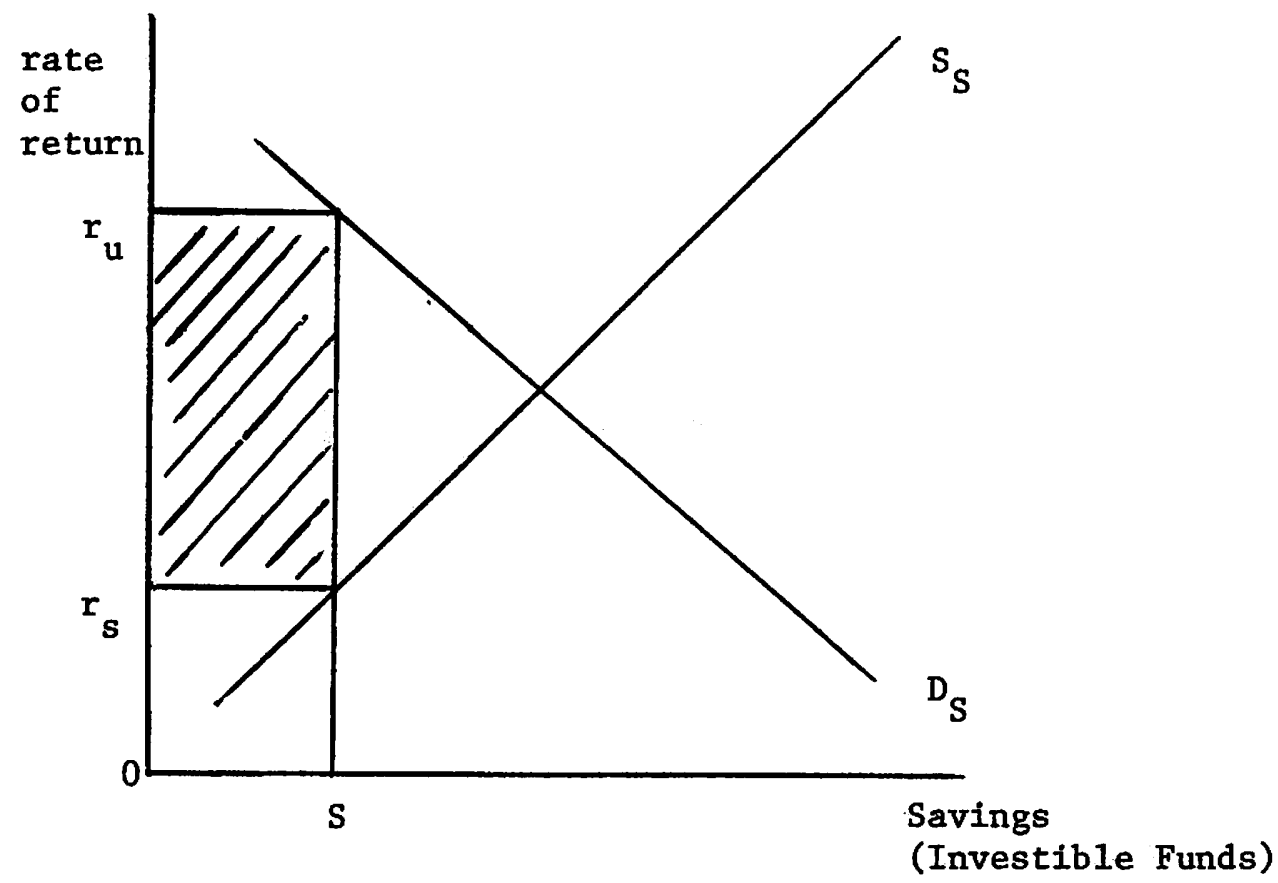


figure across industries based on a number of studies estimating the real rate of return to capital in India. As our savings figure we use household financial asset accumulation ${ }^{1}$ rather than total savings. Total savings includes government savings which itself is subject to rent seeking because of the allocation rules used within the government sector. Government savings are excluded in the rent seeking calculation reported here to provide a more conservative estimate of rent seeking costs.

Rates for short-term deposits in $1980-81$ were in the range 7.5 to $10 \%$ (nominal) longer term rates were in the range of $9-16 \% .^{2}$ During this period the inflation rate was approximately $15 \%$, so that even assuming savers were non-taxable on income from savings, real rates were very small if not negative. To err on the generous side, we use a figure for the deposit rate paid to savers of 1 to $2 \%$ real.

Nominal lending rates of financial institutions in 1980-81 were considerably above the short-term deposit rate on loans, with rates ranging between 13.5 and $19.5 \%$. However, these are also regulated through financial market controls and to evaluate the incentives to engage in rent seeking activity in capital markets it is necessary to estimate what return investors could obtain on capital through investment in real capital.

It is a somewhat difficult question to estimate what the real return to capital is in India partly because rent seeking generates a significant amount of excess capacity in several industries. Other industries where capital utilization rates are close to capacity provide more reasonable estimates.

\footnotetext{
$1_{\text {This exludes retained corporate earnings with which there is no rent }}$ seeking associated since the industry allocation of these funds is determined by the retention decision.

2 Report on Currency and Finance 1980-81, Reserve Bank of India, pp. 68-69.
} 
The low or zero rates on additional capital in excess capacity industries does not reflect the private return on investment in these industries since the return to rent seeking has to be added into the traditionally measured rate of return. The real rate of return on capital in India has, however, been estimated: in a number of recent papers and estimates are uniformly large. Lal (1977), for instance, suggests that the real rate of return to capital in India is around 10-11\%. Harberger (1974) has estimated the real return to capital at $10 \%$ or more, and Chakravarty, in a well-known paper in 1964, suggested a range of $8-12 \%$. Other sources suggest even larger numbers. Shaw (1973), for instance, suggests a range of $19 \%$ to $27 \%$, and in two recent papers Sinha (1978) and Saluja (1980) have produced estimates significantly above this.

If we were to assume the real rate of return to capital in India to be around $10 \%$ real, the differential between the real rate paid to depositors and the rate of return on capital would involve a factor of at least 5 to 1 . On this basis, if the value of savings represents the discounted present value of the return which individuals would receive from their savings then the annual flow cost of rent seeking would be five times household savings. In 1980-81, household financial savings in India amounted to snme 86 billion rupees. We err on the conservative side in our cost estimate and take a range between 1 and 2 times the value of household savings, between 85 and 170 billion rupees in $1980-81$.

\section{3) Goods Market Controls}

In goods markets a large number of commodities are subject to price controls. Excluding agricultural products, the main categories of these are fertilizer, paper, cement, commerical vehicles, automobile and allied products, drugs and pharmaceuticals, chemicals, steel, hydrocarbon oils, hydrogenated oils and edible oils, petroproducts, and tractors. Most of these items are under 
Figure 4

Rent Seeking Costs From Goods Market Controls

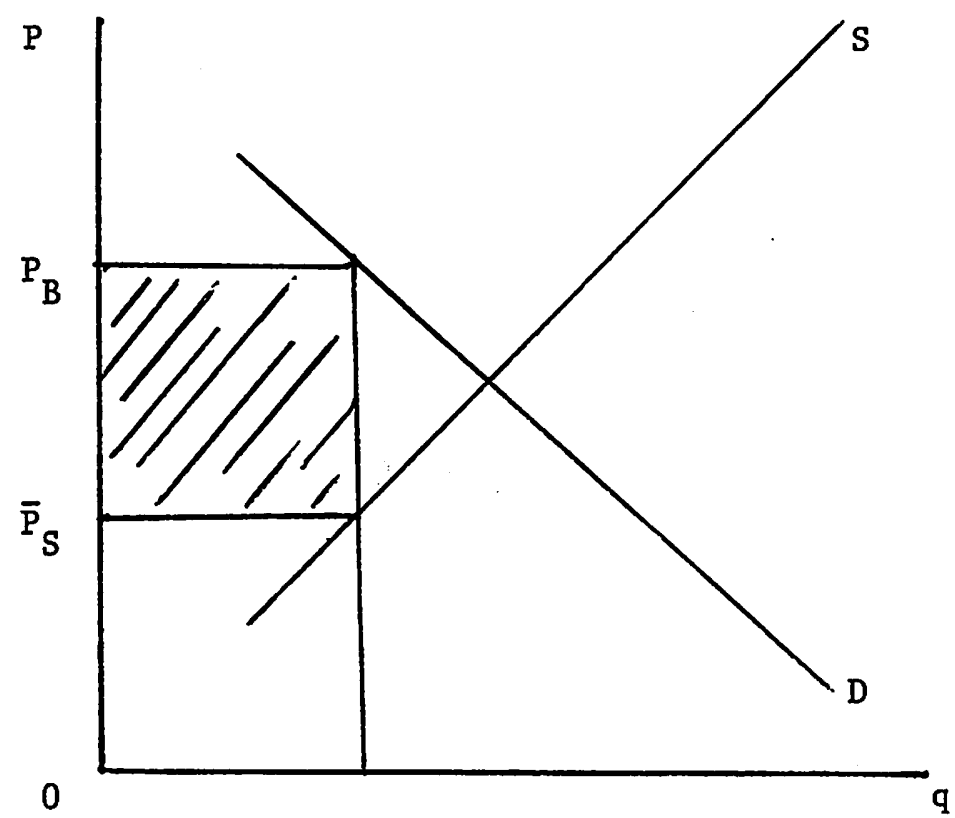


comprehensive controls even though active black markets operate. The rent seeking incentive, illustrated in Figure 4, is to obtain allocations at controlled prices $\overline{\mathrm{P}}_{S}$ and resell at higher black market prices $\mathrm{P}_{\mathrm{B}}$. While there is a risk of prosecution assoclated with transacting at the black market price, and thus the expected risk free equivalent to a black market trader is below the prevailing black market price, in recent years prosecutions have been few. We therefore ignore this effect as small.

The key issue in evaluating the cost of rent seeking associated with these controls is thus to evaluate the differential (premium) between controlled and black market prices. We appeal to a series of papers on price controls in India. Minhas (1975) suggests that in the case of cement the difference between controlled and the black market price is more than $100 \%$. A similar conclusion is reached by Char $(1979 / 81)$ in his analysis of price controls in steel, and similar differences on a range of price controlled items are reported by Srinivasan (1974). If we assume a $100 \%$ differential between controlled and black market prices for non-agricultural price controlled items, the rent seeking costs associated with these products are equal to the value of production at control prices. We estimate the sum of the output of the non-agricultural price controlled items listed above at around 170 billion rupees in 1980-81. 1

The production of controlled items in agriculture is valued at 182 billion rupees in 1979-80..$^{2}$ Approximately $30 \%$ of agricultural production of these items is sold at controlled prices, with an average free market premium of around $50 \%$. We therefore take a range of 170 to 210 billion rupees as the cost of rent seeking

$1_{\text {This }}$ is the total value of production of steel, cement, fertilizer, automobiles, chemicals, pharmaceuticals (including drugs), sugar, paper, petroleum products, and tractors. 170 billion rupees is the figure obtained from The Technical Note on the Sixth Plan 1980-85.

${ }^{2}$ See National Accounts Statistics $1970 / 71-1979 / 80$, C.S.O. Feb. 1982. Rice production is 82.7 bill., wheat R 42.0 bill., oilseeds Rs 31.9 bill., and sugar Rs 25.9 bill. 
associated with all price control items. 170 billion rupees reflects nonagricultural price controls, and 40 billion rupees agricultural price controls.

4) Labour Market Controls

With labour market controls we concentrate on rent seeking generated by high government wage rates and the entrance qualifications system. We use the wage bill in government along with an estimate of the premium paid to workers in the government sector. The total wage bill of both public administration, defense and other administrative departments in 1979-80 was 63.9 billion rupees, including pay of the army. It is widely accepted that In India the real wages of military personnel are considerably above those obtained by comparable employees in the free portion of the labour market. The differential between government wages and free sector wages has been discussed in recent literature, ${ }^{1}$ although no clear consensus as to the size of the differential has yet emerged. We assume that the differential is in the region of $50 \%$, which involves an estimate of 30 billion rupees for rent-seeking costs in labour markets in $1978 / 80$ which we also assume applies for $1980 / 81$.

V. Overall Evaluation

The estimates of rent seeking costs provided above combine to yield a range of 325 to 450 billion rupees in 1980-81, as reported in Table 2. Given an Indian GNP of around 1 trillion rupees (1042 billion ${ }^{2}$ in 1980-81), this produces an estimate of the cost of rent seeking of approximately $30-45 \%$ of national income in 1980-81. No double counting is involved in combining these separate rent

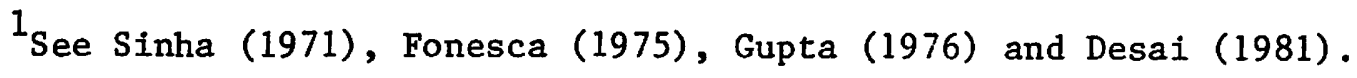

2 Quick Estimate of National Income, Saving, Consumption Expenditure and Capital Formation 1980/81, C.S.0., New Dehli, 1982. 
Table 2

Estimates of the Cost of Rent Seeking

In India 1980-81

\section{Source}

Import Licenses and Export Incentives

Capital Market Controls

Coods Market (price) Controls

Labour Market Controls
Rs. billion

40

$85-170$

$170-210$

30

$325-450$

1042

$30-45 \%$

Rent seeking costs as a \% of GNP (approximate) 
seeking costs, although were a more formally complete general equilibrium model to be used to evaluate the no distortion situation, relative prices would change and these estimates would differ somewhat. We nonetheless believe that large cost estimates would remain.

As mentioned in the introduction, these loss estimates are approximately compatible with calculations of the cost of rent seeking using a residual method. This can be seen as follows. According to the report of the Import Substitution Committee in 1980, data on capacity utilization rates in a range of manufacturing industries suggests that at least half of the industries considered had unused capacity up to $35 \%$ or even more. Very few had achieved capacity utilization rates as high as 70 to 80 percent. A related piece of evidence is contained in a recent analysis by Goyal (1982) of 3,000 investment licenses issued in 1979 . He found that in $46 \%$ of the cases considered where capacity was authorized and subsequently installed, it was only used up to $25 \%$ of the capacity which was licensed. Only for $31 \%$ of the licenses issued for industrial licensing was the utilization between 25 and 75\%. Bhagwati and Srinivasan (1975) and Raj (1976) also highlight low capacity utilization rates in India as being key to an understanding of Indian policy issues.

Thus if we assume an average capacity utilization rate for India of approximately $60 \%$ and combine this with overmanning rates in the range of 40 to $50 \%$ (see Desai (1981)), the combination of unused capacity and overmanning gives an indirect estimate of rent seeking costs by residual. 1 These can be seen to be approximately consistent with the numbers which we report in Table 2 .

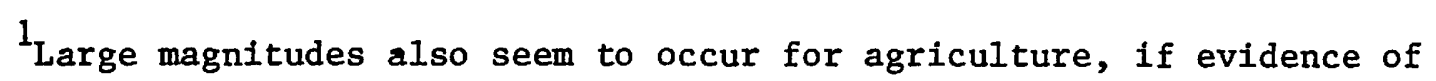
underutilization of land and labour is used. Surplus labour in agriculture is more than $40 \%$ according to Mitra (1976) and around $30 \%$ due to Rudra (1973). 
A further indirect check on the reliability of the range we suggest is provided by estimates of the size of the black (underground) economy in: India. The black economy reflects both tax evasion and participation in illegal activities which violate the price control and other regulations. As such it does not provide an exact measure of the value of rents generated by controls, but nonetheless provides some indication. It seems generally agreed that the size of the black economy in India is growing over time, and some recent estimates $^{1}$ have suggested that it might be as large as $40 \%$ of GNP. V. Conclusion

In this paper we present estimates of the annual welfare costs of rent seeking in India. Our calculations seem to indicate that the costs involved may well be considerably larger than those suggested in the original rent seeking paper by Krueger (1979). We produce a range of cost estimates of around 30 to 45 percent of national income per year, suggesting that rent seeking may be one of the paramount policy issues in India for anyone concerned both with resource allocation, and increasing real consumption standards.

\footnotetext{
${ }^{1}$ See Gupta and Gupta (1982), and Gupta and Mehta (1982).
} 
Bhagwati, J.N. and T.N. Srinivasan (1980): Revenue Seeking: A Generalization of the Theory of Tariffs, Journal of Political Economy, vol. 88, No. 6 . and Development, India, NBER. (1975): Foreign Trade Regimes and Economic

Bhagwati, J.N. (1982): Directly Unproductive, Profit-Seeking (DUP) Activities, Journal of Political Economy, vol. 90, No. 5.

Buchanan, J.M., R.D. Tollison and G. Tullock. Towards a Theory of the Rent Seeking Society, Texas A\&M University Press, 1980.

Chakravarty, S. (1964): The Use of Shadow Prices in Programme Evaluation, in Capital Formation and Economic Development (ed.) Rodenstien Rodan.

Char, S.V. (1981): Experiments in Steel Pricing, Economic and Political Weekly, Feb. 28.

(1979): Steel Pricing and Distribution, Economic and Political Weekly, May 5 .

Chetty, V. K. (1982): Surplus Sugar Burden, Case for Boosting Consumption, Economic Times, July 10.

Dantawala, M.L. (1970): From Stagnation to Growth, Text of Presidential Address to 53rd Annual Conference of Indian Economic Association, Indian Economic Journal, Oct.-Dec., vol. XIX, No. 2.

Datta, B. (1978): How Best to Utilize the Mounting Foreign Exchange Reserves, Supplement to Capital, March 23.

Desai, Ashok V. (1981): Factors Underlying the Slow Growth of Indian Industry, E.P.W., Annual Number, March.

Foresca, A.J. (1975): Wage Issues in a Developing Economy: The Indian Experience, Bombay, Oxford University Press.

Goyal, S.K. (1982): New Industrial Licensing Policy, Eastern Economist, Apri1 30, 1982.

Gupta, G.S. (1980): Agricultural Price Policy and Farm Incomes, E.P.W., Sept. Review of Agriculture, (See also the Editorial of same no.).

Gupta, H.C. (1976): Economics of Trade Unionists, India.

Gupta, S. and R. Mehta (1982): An Estimate of Underreported National Income, Planning Commission, New Delhi.

Harberger, A.C. (1964): Taxation, Resource Allocation, and Welfare, in the role of Direct and Indirect Taxes in the Federal System, Princeton University Press for NBER and the Brooking Institute.

(1972): Project-Evaluation: Collected Papers. Investment in Men Versus Investment in Machines: Case of India, Chicago (Malkham Pubs.). 
Hotelling, H. (1938): The General Welfare in Relation to Problems of Taxation and of Railway and Utility Rates, Econometrica, July.

Krishna, Raj (1967): Agricultural Price Policy and Economic Development,in Southworth and Johnston (eds.), Agricultural Development and Economic Growth, Cornell.

Krueger, A.0. (1974): The Political Economy of the Rent-Seeking Society, American Economic Review, June, 64, 291-303.

Lal, Deepak (1977): Distribution Weights, Shadow wages, Accounting Rate of Investment-Estimates for India, Indian Economic Review.

Mellor, John (1968): The Economics of Agricultural Development, Bombay.

Minhas, B.S. (1975): Design of Economic Policy and the Phenomenon of Corruption: Some Suggestions for Economic Reforms, Journal of Social and Economic Studies, September.

Mitra, Ashok K. (1976): Surplus Labour in Agriculture, E.P.W., July 10.

Monteiro, J.B. (1966): Corruption, Bombay .

Raghavachari, M.V. (1979): Growth of Budgetary Subsidies of Central Government, E.P.W., Marhc 3 .

Raj, K.N. (1976): Growth and Stagnation in Indian Industrial Development, Economic and Political Weekly, Annual Number.

Rao, C.H.H. (1975): Technological Change and Distribution of Gains in Indian Agriculture, McMillan.

Rudra, Ashok (1973): Direct Estimation of Surplus Labour in Agriculture, E.P.W., Annual Number.

Saluja, M.R. (1980): Incremental Capital-Output Ratio, Sankhya, 1980.

Sau, Ranjit (1976): Land Utilization: A Note, E.P.W., September 4.

Shaw, E.S. (1973): Financial Deepening in Economic Development, Chapters 1 \& 2, Oxford University Press, New York.

Sinha, C. (1978): Financial Intermediation and Rural Development - Rate of Return to Capital in Agriculture, Indian Economic Journal, Sepecial Issue, vol. 26 , No.3.

Sinha, R.P. (1971): Wage Determination, Asia Publication, New Yărk.

Srinivasan, T.N. (1974): Income Distribution: A survey of Policy Aspects, Sankhya, Series C.

Verghese, S.K. (1978): Export Assistance, Policy and Export Performance in India in the Seventies. E.P.W., Annual Number. 
Main Sources of Data

National Accounts Statistics, 1970-71, 1979-80, C.S.0., 1982.

Report on Currency and Finance 1980-81, Volume II, R.B.I., 1982.

Report of the Import Substitution Comnittee, Ministry of Industry, Sept. 1980.

Report of the Committee on Import-Export Policies and Procedures, Ministry of Commerce, January 1978.

Report of the Committee on Export Strategy 1980s, Ministry of Commerce, May, Dec. 1980.

Import and Export Policy, April 1982 -March 1983, Volume I, Imports and Export Promotion, Ministry of Commerce, 1982. 
1982

8201C Manning, Richard and James R. Markusen: DYNAMIC NON-SUBSTITUTION AND LONG RUN PRODUCTION POSSIBILITIES

8202C Feenstra, Robert and Ken Judd: TARIFFS, TECHNOLOGY TRANSFER, AND WELFARE

8203C Ronald W. Jones and Douglas D. Purvis: INTERNATIONAL DIFFERENCES IN RESPONSE TO COMMON EXTERNAL SHOCKS: THE ROLE OF PURCHASING POWER PARITY

8204C James A. Brander and Barbara J. Spencer: INDUSTRIAL STRATEGY WITH COMMITTED FIRMS

8205C Whalley, John: THE NORTH-SOUTH DEBATE AND THE TERMS OF TRADE: AN APPLIED GENERAL EQUILIBRIUM APPROACH

8206C Betancourt, Roger; Christopher Clague and Arvind Panagariya: CAPITAL UTILIZATION IN GENERAL EQUILIBRIUM

8207C Mansur, Ahsan H.: ON THE ESTIMATION OF IMPORT AND EXPORT DEMAND ELASTICITIES AND ELASTICITY PESSIMISM

8208C Whalley, J. and Randy Wigle: PRICE AND QUANTITY RIGIDITIES IN ADJUSTMENT TO TRADE POLICY CHANGES: ALTERNATIVE FORMULATIONS AND INITIAL CALCULATIONS

8209C DSU Jimenez, E.: SQUATTING AND COMMUNITY ORGANIZATION IN DEVELOPING COUNTRIES: A CONCEPTUAL FRAMEHORK

8210C Grossman, G.M.: INTERNATIONAL COMPETITION AND THE UNIONIZED SECTOR

8211C Laidler, D.: FRIEDHAN AND SCHWARTZ ON MONETARY TRENDS--A REVIEW ARTICLE

8212C Imam, H: and John Whalley: INCIDENCE ANALYSIS OF A SECTOR SPECIFIC MINIMUM WAGE IN A THO SECTOR HARRIS-TODARO MODEL

8213C Markusen, James R. and James R. Melvin: THE GAINS FROM TRADE THEOREM WITH INCREASING RETURNS TO SCALE

8214C Harris, Richard: INDUSTRIAL ORGANIZATION AND THE GENERAL EQUILIBRIUM COSTS OF PROTECTION IN SMALL OPEN ECONOMIES

8215C Laidler, David: DID MACROECONOMICS NEED THE RATIONAL EXPECTATIONS REVOLUTION?

8216C John Whalley and Randall Wigle: ARE DEVELOPED COUNTRY MULTILATERAL TARIFF REDUCTIONS NECESSARILY BENEFICIAL FOR THE U.S.? 
8217 Bade, Robin and Michael Parkin. IS STERLING M3 THE RIGHT AGGREGATE?

8218 Kosch, Bernd. FIXED PRICE EQUILIBRIA IN OPEN ECONOMIES

1983

8301 Harrison, Glenn and Larry Kimbel1. ON THE SOLUTION OF GENERAL EQUILIBRIUM MODELS

8302 Melvin, James. A GENERAL EQUILIBRIUM ANALYSIS OF CANADIAN OIL POLICY

8303 Markusen, James and Lars Svenssion. TRADE IN GOODS AND FACTORS WITH INTERNATIONAL DIFFERENCES IN TECHNOLOGY 